\title{
DigITALCOMMONS
}

—@WAYNESTATE-

Wayne State University

$1-1-2012$

\section{The Predicament of China's "WTO-Plus" Obligation to Eliminate Export Duties: A Commentary on the China-Raw Materials Case}

Julia Ya Qin

Wayne State University

\section{Recommended Citation}

Qin, Julia Ya. The Predicament of China's "WTO-Plus" Obligation to Eliminate Export Duties: A Commentary on the China-Raw Materials Case. 11 Chinese J. Int'1 L. 237 (2012)

Available at: https://digitalcommons.wayne.edu/lawfrp/255 


\title{
Editorial Comments
}

\section{The Predicament of China's "WTO-Plus" Obligation to Eliminate Export Duties: A Commentary on the China-Raw Materials Case}

\author{
Julia Ya Qin*
}

1. The recent rulings of the Dispute Settlement Body of the World Trade Organization in China-Raw Materials ${ }^{1}$ have important legal and policy implications. At issue was China's use of tariffs and nontariff measures to restrict the export of nine raw materials (bauxite, coke, fluorspar, magnesium, manganese, silicon carbide, silicon metal, yellow phosphorus and zinc). The complainants-the United States, the European Union and Mexico-challenged China's export restraints as violations of the provisions of the General Agreement on Tariffs and Trade ("GATT") and China's Protocol of Accession (the "Protocol"). ${ }^{2}$ China defended its measures by invoking GATT Article XX(g), which excuses measures relating to the conservation of exhaustible natural resources, and Article $\mathrm{XX}(\mathrm{b})$, which allows measures necessary to protect human, animal or plant life or health. China's defense, however, was rejected by the WTO judiciary.

2. The WTO judiciary made two key findings. First, it found that China's export duties breached China's obligation to eliminate export duties under paragraph 11.3 of the Protocol, and that China may not invoke GATT Article XX to justify this breach, because there is no textual link between paragraph 11.3 and the GATT provision. Second, it found that China's export restrictions violated GATT Article XI:1,

* Professor of Law, Wayne State University Law School, U.S.A.; Editor of this Journal.

1 Panel Reports, China-Raw Materials, WT/DS394, 395, 398/R, as modified by the Appellate Body Reports, WT/DS394, 395, 398/AB/R ("AB Reports"), were adopted by the DSB on 22 February 2012.

$2 \mathrm{WT} / \mathrm{L} / 432$ (10 November 2001). 
which prohibits all quantitative restrictions on imports and exports, and that the violation cannot be excused by the environmental exceptions under Article XX(b) or (g) because China failed to demonstrate that it has similarly restricted domestic consumption.

3. The WTO rulings have serious implications for China's industrial and environmental policies. For years, China has overexploited its natural resources at the expense of environmental degradation and resource depletion. With only limited natural endowments, China nonetheless has been exporting raw materials at cutrate prices, driving out foreign competition and making itself a major supplier to the rest of the world. Meanwhile, rapid industrialization at home has increased domestic demand for raw materials tremendously. Realizing that China badly needs to conserve exhaustible natural resources and to protect the environment, but desiring not to hinder development of domestic downstream industries, the government has resorted to export restrictions to reduce foreign consumption without simultaneously curbing domestic consumption. This policy, however, can no longer be pursued. Under the WTO rulings, China must treat domestic and foreign users evenhandedly in the distribution of its resource products. Domestic industries may not be given preferences over foreign purchasers with respect to access to China's raw materials. If for whatever reason China is unable to implement proper environmental standards in the production of raw materials, resulting in "subsidization" of its domestic industries with low-priced resources, then it must do the same for foreign buyers, while bearing the consequences of environmental degradation at home.

4. Soon after the WTO rulings in China-Raw Materials, the United States, the EU and Japan filed another WTO case, challenging China's export restrictions on rare earths, tungsten and molybdenum. ${ }^{3}$ The issues involved in this new case are almost identical with those in China-Raw Materials, except the stakes are even higher due to the strategic importance of rare earths for high tech industries. Given the outcome of China-Raw Materials, China faces an uphill battle in defending its rare earths measures.

\section{China's Predicament Stems from its "WTO-Plus" Obligation to Eliminate Export Duties}

5. It is important to understand that China's predicament stems from its special commitment to eliminate export duties. Currently, GATT rules prohibit quantitative restrictions on exports, but permit the use of export tariffs. Since tariff and nontariff measures can achieve the same effect of limiting exports, the WTO discipline on export restrictions has been rendered largely ineffective. Efforts to tighten the 
discipline have met with continued resistance from developing countries, which regard the flexibility to restrict exports as essential for maintaining sovereignty over natural resources and for developing domestic downstream industries. Despite the lack of a general discipline on export tariffs, the WTO has nonetheless required a few acceding countries, including China, to make commitments on export duty as part of the conditions for their accessions to the WTO.

6. The export-duty commitments of the acceding countries vary widely in scope and content. Compared to others, China's commitments are among the most comprehensive. Specifically, China agreed to eliminate export duties on all but 84 products, and for those 84 products, not to apply duties exceeding the maximum rates specified. By undertaking such a sweeping obligation, however, China has forfeited its freedom to restrict exports, which is otherwise available under the generally applicable WTO rules. Put differently, if it were not for this "WTO-plus" obligation, China would still be able to rely on tariffs as the main policy tool to control the export of exhaustible natural resources, avoiding the need to use quotas and other nontariff measures that are strictly regulated under the WTO agreements.

7. Legally, the Protocol constitutes "an integral part" of the WTO Agreement, ${ }^{4}$ and as such, its provisions are enforceable through the WTO dispute settlement mechanism. The Protocol, however, does not specify how its WTO-plus provisions should be "integrated" with the generally applicable WTO rules. As a result, their interpretation remains a special challenge.

\section{Applicability of GATT Policy Exceptions to China's Export-Duty Commitments}

8. A major interpretive issue in this case is the applicability of GATT exceptions to China's export-duty commitments under the Protocol. Whether a member-specific obligation contained in an accession protocol is entitled to the policy exceptions provided in the multilateral WTO agreements, such as GATT Articles XX (general exceptions) and XXI (security exceptions), raises a systemic question as to the relationship between different legal instruments within the framework of the WTO Agreement. Thus far, the WTO's Appellate Body has taken a strict textualist approach, pursuant to which the applicability of GATT exceptions to an accession commitment hinges on whether there is an explicit textual link between them. Accordingly, in China-Publications and Audiovisual Products, the Appellate Body held that China may invoke GATT Article XX to defend the breach of its trading-rights commitments set out in paragraph 5.1 of the Protocol, because the introductory phrase of paragraph 5.1 provides such a textual link (stating that the trading-rights commitments are "without prejudice to China's right to regulate 
trade in a manner consistent with the WTO Agreement"). ${ }^{5}$ In China-Raw Materials, by contrast, the Appellate Body rejected the applicability of GATT Article XX to China's export-duty commitments, because it could not find a similar textual link in paragraph 11.3 of the Protocol.

9. Paragraph 11.3 of the Protocol provides: "China shall eliminate all taxes and charges applied to exports unless specifically provided for in Annex 6 of this Protocol or applied in conformity with the provisions of Article VIII of the GATT 1994." Annex 6 sets out a table listing 84 commodities subject to export duties and a maximum duty rate for each commodity. Article VIII of the GATT 1994 contains rules on customs fees and charges other than import or export duties. The fact that paragraph 11.3 expressly refers to GATT Article VIII, but not other GATT provisions, including Article XX, was considered significant by the WTO judges. ${ }^{6}$ Upon examining a few other provisions in the Protocol and the Working Party Report on China's Accession, ${ }^{7}$ the Appellate Body concluded:

In the light of China's explicit commitment contained in Paragraph 11.3 to eliminate export duties and the lack of any textual reference to Article XX of the GATT 1994 in that provision, we see no basis to find that Article XX of the GATT 1994 is applicable to export duties found to be inconsistent with Paragraph $11.3^{8}$

10. This narrow textualist approach, unfortunately, has led to an irrational and undesirable result for the WTO. The general exceptions of GATT Article XX are designed to safeguard important public policies and non-trade values from being infringed upon by obligations to liberalize trade. They apply to all GATT obligations, including the fundamental principles of most-favored-nation ("MFN") treatment and national treatment. (Similar policy exceptions are provided for all obligations to liberalize service trade, under the General Agreement on Trade in Services ("GATS"), Article XIV.) By holding China's export-duty commitment immune from policy exceptions, the WTO judiciary has effectively turned this particular trade-liberalization commitment into the most "sacred" obligation within the WTO system. From a policy standpoint, the W'TO ruling sends a powerful message: without an express textual reference, individual trade-liberalization obligations will be interpreted to trump public policy and nontrade values under WTO law.

11. The narrow textualist approach adopted by the WTO judiciary is also problematic in light of the interpretive principles of the Vienna Convention on the Law of Treaties ("VCLT"), which guide the interpretation of all WTO agreements. As

5 WT/DS363/AB/R (21 December 2009), paras.229-233.

6 Panel Reports, above n.1, para.7.129; AB Reports, above n.1, para.303.

$7 \mathrm{WT} / \mathrm{MIN}(01) / 3$ (10 November 2001).

8 AB Reports, above n.1, para.306. 
the Appellate Body noted, "Paragraph 1.2 of China's Accession Protocol provides that the Protocol 'shall be an integral part' of the WTO Agreement. As such, the customary rules of interpretation of public international law, as codified in Articles 31 and 32 of the Vienna Convention on the Law of Treaties . . ., are, pursuant to Article 3.2 of the DSU, applicable in this dispute in clarifying the meaning of Paragraph 11.3 of the Protocol."9

12. According to VCLT Article 31(1), "a treaty shall be interpreted in good faith in accordance with the ordinary meaning to be given to the terms of the treaty in their context and in the light of its object and purpose." The "context" for the terms of a treaty is defined broadly under Article 31(2) to comprise both the textual context of the treaty, "including its preamble and annexes", and any prior agreement concluded between all the parties in connection with the treaty. Article 31(3) further requires a treaty interpreter to take into account, together with the context, any subsequent agreement and practice that forms agreement between the parties regarding the interpretation of the treaty, as well as "any relevant rules of international law applicable in the relations between the parties". If the interpretation according to Article 31 "leads to a result which is manifestly absurd or unreasonable", Article 32 allows the treaty interpreter to have recourse to "supplementary means of interpretation, including the preparatory work of the treaty and the circumstances of its conclusion" in order to determine the meaning. In short, the VCLT prescribes a broad contextualist approach towards treaty interpretation.

13. In contrast, the Appellate Body in this case focused narrowly on the text of paragraph 11.3 and limited its contextual examination to a few paragraphs in the Protocol and the Working Party Report, to the exclusion of all other elements articulated in VCLT Articles 31 and 32. The interpretive task at hand was to ascertain the common intention behind the absence of an explicit reference to GATT Article XX in paragraph 11.3. In principle, the absence of a term in a treaty provision does not necessarily mean that nothing is implied. As the Appellate Body itself once observed, "the task of ascertaining the meaning of a treaty provision with respect to a specific requirement does not end once it has been determined that the text is silent on that requirement. Such silence does not exclude the possibility that the requirement was intended to be included by implication." ${ }^{10}$ Whether something is implied in the silence depends on what that "something" is, and on the nature of the treaty and the interaction of the various elements of the VCLT rules. ${ }^{11}$ The risk is to be averted that "the contracting parties may, by judicial

9 Ibid., para.278.

10 Appellate Body Report, US-Carbon Steel, WT/DS213/AB/R (28 November 2003), para.65.

11 Richard Gardiner, Treaty Interpretation (Oxford University Press, 2008), 145. 
interpretation, become bound by obligations they did not expressly accept and might not have been willing to accept." 12

14. In this particular instance, the "something" that may be implied in the silence in paragraph 11.3 is a set of public policies that WTO Members have accepted as prevailing over all GATT obligations on liberalization of trade. Although not formally incorporated into the GATT, China's export-duty commitments are nothing but deeper commitments to liberalize trade. From a systemic viewpoint, there is no reason why such commitments should be made immune from public policy considerations. The systemic importance of the policy exceptions and the nature of China's commitments both counsel against an inference from the silence in paragraph 11.3 that China had intended-and other WTO Members had in good faith expected China to agree-to insulate these particular commitments from all policy considerations and nontrade values under WTO law. ${ }^{13}$

15. The nature of the Protocol also counsels against such an inference. Unlike the multilateral agreements annexed to the WTO Agreement, WTO accession protocols are not devoted to a single subject matter, such as trade in goods or services, intellectual property rights and investment measures. Instead, the accession protocol sets out the terms of accession for a particular country that cover subjects across the entire spectrum of the WTO Agreement. For this reason, it does not provide a coherent set of general exceptions on its own. Typically, a special commitment of the acceding country is built upon, and is intrinsically related to, one or more generally applicable obligations under the multilateral WTO agreements. The export-duty commitments, for example, are built upon and inherently related to the GATT obligations concerning customs tariffs and quantitative restrictions. The fact that these GATT obligations are all subject to the policy exceptions in Article XX suggests that China might reasonably expect the same policy exceptions to be available to its export-duty commitments.

16. How to interpret the silence in paragraph 11.3 also depends on the interaction of the various elements of the VCLT interpretive principles. When the object of interpretation is the absence of a term, the "ordinary meaning" of the term does not exist, hence its implication can only be interpreted contextually, that is, through the examination of all other elements articulated in VCLT Articles 31 and 32 in a holistic manner. Because the Protocol constitutes "an integral part" of the WTO Agreement, pursuant to Article 31(2), the textual context of the Protocol should comprise the entire WTO Agreement, including its preamble and annexes. The GATT 1994, being one of the annexes to the WTO Agreement,

12 Id., 147.

13 China argued that its right to regulate trade is "an inherent right", and not a right bestowed by international treaties such as the WTO Agreement. According to China, the Protocol and Working Party Report contain no language showing that China has abandoned its inherent right to regulate trade. AB Reports, above n.1, para.300. 
should therefore be viewed as part of the "context" of the Protocol. And the GATT provisions on export restraints, including the exceptions applicable to them, should all be treated as the relevant context of paragraph 11.3 and be examined as such in the process of ascertaining the implication of the silence. This, however, was not recognized by the Appellate Body.

17. Pursuant to VCLT Article 31(1), the interpretation of the silence shall also be made "in the light of object and purpose" of the treaty. In interpreting paragraph 11.3, the Appellate Body referred to the various objectives listed in the preamble of the WTO Agreement, including those of environmental protection and preservation, sustainable development and the development of an integrated, more viable and durable multilateral trading system. The Appellate Body stated that based on the language of the preamble, it understood "the WTO Agreement, as a whole, to reflect the balance struck by WTO Members between trade and non-trade-related concerns." ${ }^{14}$ However, it quickly declared that "none of the objectives listed above, nor the balance struck between them, provide specific guidance on the question of whether Article XX of the GATT 1994 is applicable to Paragraph 11.3 of China's Accession Protocol." ${ }^{15}$ This summary dismissal of the interpretive value of the WTO objectives betrays a profound misunderstanding of the role of "object and purpose" in treaty interpretation. Instead of seeking "light" from the objectives of the WTO Agreement, the Appellate Body was looking for "specific guidance" on a particular interpretive question. Since the broad objectives of the WTO Agreement can never provide specific guidance on any particular interpretive issue, the Appellate Body in this case effectively relegated the element of "object and purpose" to futility.

18. In accordance with VCLT Article 32, if the interpretation according to Article 31 "leads to a result which is manifestly absurd or unreasonable", the treaty interpreter may resort to supplementary means of interpretation to determine the meaning. Here, the interpretive result reached by the Appellate Body should have been recognized as "manifestly unreasonable", for it simply does not make sense that the special trade-liberalization commitments of China should become the most "sacred" obligation within the WTO system. Given the absurdity of the result, the WTO judges should have resorted to supplementary means, including the preparatory work and the circumstances surrounding the conclusion of the Protocol, to help ascertain the actual common intention behind the silence in paragraph 11.3. That, of course, was not the case. Instead of making an effort to examine the historical context in which China's export-duty commitments were made, the Appellate Body simply decided that "as China's obligation to eliminate export duties arises exclusively from China's Accession Protocol, not from the

14 Ibid., para.306 (emphasis original).

15 Ibid. (emphasis added). 
GATT 1994, we consider it reasonable to assume that, had there been a common intention to provide access to GATT Article XX in this respect, language to that effect would have been included in Paragraph 11.3 or elsewhere in China's Accession Protocol."16

19. This "reasonable" assumption of the Appellate Body, however, disregards the political reality of accession negotiations. Unlike WTO multilateral negotiations, in which diverse interests among Members can be expected to provide the checks and balances necessary to produce carefully-drafted rules, WTO accession is a process in which the applicant country must negotiate against the entire incumbent membership, through both bilateral and multilateral procedures. In such a process, whether a particular term was well negotiated and carefully drafted would depend not only on the bargaining power of the applicant in specific negotiations, but also on the level of legal sophistication and competence of its negotiation team and the quality of its domestic decision-making process. Due to its lack of prior WTO experience and adequate legal capacity at the time of accession, China accepted many loosely drafted terms in the Protocol. Paragraph 11.3 has proven to be one of them. It is hard to imagine that if China had been asked explicitly during the accession negotiations whether its export-duty commitments should be entitled to the policy exceptions provided in GATT Article XX, it would have answered the question in negative. And it is equally hard to imagine that had China articulated such a position, WTO Members would have opposed to it, as there is absolutely no systemic or policy reason to deny the applicability of these exceptions to the export-duty commitments. In this regard, it is also worth noting that countries acceding to the WTO subsequently have the chance to learn lessons from China's experience and to improve the drafting of their terms of accession. The inclusion of an explicit reference to GATT Article XX in Ukraine's export-duty commitments is such an example. ${ }^{17}$

20. In sum, the text of the Protocol leaves large gaps for the treaty interpreter to fill, thus posing a considerable interpretive challenge to the WTO judiciary. Confined to its narrow textualist approach, the WTO judiciary was unable to meet the challenge in this case. The outcome is a highly irrational and undesirable state of affairs being created within the WTO.

\section{Can China's Obligation on Export Duty Be Revised?}

21. China would have lost its defense even if GATT Article XX had been held applicable to paragraph 11.3 of the Protocol. The WTO Panel in this case did apply Article XX to paragraph 11.3 on an arguendo basis, and found that China had failed

16 Ibid., para.293.

17 See WT/ACC/UKR/152 (25 January 2008), para.40. 
to demonstrate that its export duties can be justified by Article $\mathrm{XX}(\mathrm{b})$ or $(\mathrm{g}) .^{18}$ Because China had not imposed similar taxes and restrictions on domestic consumption of the raw materials subject to export duties, it could not meet the requirement of Article XX(g) that measures for conserving exhaustible natural resources be "made effective in conjunction with restrictions on domestic production or consumption"; nor could it persuade the Panel that its export restraints are "necessary" to protect public health under Article XX(b).

22. Legally, none of the GATT exceptions applicable to export restraints is designed to protect or promote domestic industries. Consequently, a WTO Member cannot claim a larger share in the distribution of its natural resources for the benefit of its domestic industries through any GATT exceptions. This constraint does not matter much for most WTO Members, who remain free to impose tariffs on exports. The same cannot be said for China and several other acceding countries. Through its commitment to eliminate export duties, China has effectively agreed to make its resource products available to both domestic and foreign users in a nondiscriminatory manner.

23. But can China's commitments on export duty be renegotiated and revised? The Protocol is silent concerning amendment of its provisions. In theory, the Protocol, as an integral part of the WTO Agreement, should be amendable pursuant to the procedure of amendment set out in the WTO Agreement. In practice, however, it would be extremely difficult, if not impossible, to effect such an amendment.

24. In retrospect, China's export-duty commitments should have been incorporated into its tariff schedule attached to the GATT 1994, which contains its concessions on import tariffs. To encourage commitments on tariff reductions, the WTO allows an obligation set out in a Member's tariff schedule to be modified or withdrawn on a regular basis in accordance with specific procedures. ${ }^{19}$. In practice, Members have routinely resorted to this mechanism to adjust their tradeliberalization commitments. So far, the export-dury commitments of the acceding countries have not been incorporated into their GATT schedules. But the recently concluded accession package for Russia creates a new precedent: the extensive export-duty commitments undertaken by Russia will be part of its GATT schedule, thus entitled to all the flexibilities available under GATT rules (including the GATT general exceptions).

25. Insofar as raw materials are concerned, the de facto immutability of a Member's obligation to eliminate export duties raises an issue of consistency with the principle of permanent sovereignty over natural resources. Pursuant to this generally accepted principle of international law, nations have permanent sovereignty

18 Panel Reports, above n.1, para.8.2. China did not appeal this finding.

19 See GATT art. XXVIII (Modification of Schedules). Similar flexibility is provided for commitments contained in the GATS service schedules. 
over their natural resources, including the right to dispose freely of such resources for domestic economic development. This right has also been recognized as a basic human right of all peoples under the International Covenant on Civil and Political Rights (articles 1.2 and 47) and the International Covenant on Economic, Social and Cultural Rights (articles 1.2 and 25). While the exercise of this right is without prejudice to the international obligations a nation undertakes voluntarily, the permanent character of the sovereignty implies that this right can always be regained. ${ }^{20}$ Surely, a Member can regain this right by withdrawing from the WTO altogether. But as a matter of law and policy, should the WTO not take care to respect this basic principle of international law in the design of its rules and obligations?

20 As Abi-Saab once put it, "sovereignty is the rule and can be exercised at any time" and "limitations are the exceptions and cannot be permanent, but limited in scope and time." UN Doc. A/39/504/Add.1 (23 October 1984). 